\title{
Networking behaviour, graduate employability: A social capital perspective
}

\begin{abstract}
Purpose: Drawing on the overarching framework of social capital theory this study develops and empirically examines networking behaviour and employability within the higher education context.

Design/methodology/approach: In a sample of 376 full-time business students we measured perceived employability, networking behaviour, access to resources and job-search learning goal orientation.
\end{abstract}

Findings: Networking is related to increased internal and external perceived employability by boosting access to resources. Our results also demonstrate that networking is positively related to access to resources for low and high job-search learning goal orientation, the relationship being stronger for those with higher levels.

Research implications: We contribute to social capital, networking and graduate employability literatures with an indirect model of networking outcomes in the higher education context. This shows access to resources as a mediator and job-search learning goal orientation as an intensifying characteristic.

Practical implications: Our findings suggest activities for individuals concerned with enhancing their employability and those involved in supporting career guidance.

Originality/value: Obvious beneficiaries are students, for whom employment is a key concern, and universities who face increasing pressure to enhance graduate employability whilst resources to do so are diminishing. To this end, we highlight activities that may develop networking behaviours and job-search learning goal orientation.

Key words: employability; job-search learning goal orientation; networking; social capital 


\section{Introduction}

Networking is the age-old practice of building and nurturing personal and professional links with a variety of people to create a bank of resources, including contacts, information and support. Academic and practitioner literatures assert that networking provides numerous beneficial career-related outcomes for both individuals and organizations (e.g. Fugate, Kinicki and Ashforth, 2004; Seibert, Kraimer and Liden, 2001; Wolff and Moser, 2009). One specific desirable outcome of networking is enhanced employability, through the building and maintenance of contacts that can provide relevant resources (Burt, 1997; Granovetter, 1973; Kanfer, Wanberg and Kantrowitz, 2001; Van Hoye, van Hooft and Lievens, 2009). Most research assumes a direct link between networking and employability, yet although Wanberg, Kanfer and Banas (2000) found that up to $36 \%$ of jobs are secured via networking, the results were inconsistent. They concur with others (Van Hoye et al., 2009) that networking might be indirectly related to job search success and thus question possible antecedents. We assert that access to resources might be relevant, based on social and network capital theories.

Networking creates many forms of valuable social capital including advocacy, introductions and mentoring that would otherwise require the use of human or financial capital (Simon, 2013). Specifically, social relationships can provide access to career management resources that enhance employability (Burt, 1992; Granovetter, 1973). However, having a social network does not guarantee that these effects or benefits will materialize (Adler and Kwon, 2002). Research tends to treat access to resources as self-assumed (see Anderson, 2008; Seibert, Kraimer and Liden, 2001 for some exceptions), yet network capital theory suggests that resources embedded in relationships actually need to be accessed and not just acquired in order to be valuable (Huggins, 2010). This implies a role for strategic networking behaviour, or what Huggins, Johnston and Thompson call `Calculative ties` (2012, p. 204) in order to boost 
employability. The lack of research into indirect relationships may be one explanation for inconsistencies in findings that link networking and enhanced employability (Van Hoye et al., 2009; Wanberg et al., 2000).

In response, this study empirically examines an indirect-based model that depicts resources as a central mechanism through which networking behaviour is related to perceived employability. Wanberg et al. (2000) chose unemployed job seekers to obtain a sample of those focused on employability when studying networking intensity. In a similar vein we too have chosen a sample for whom employability is highly relevant, namely university business school students (Tymon and Batistic, 2016). This use of a student sample also justifies the exploration of an individual characteristic and its links to networking behaviour- job-search learning goal orientation (JSLGO). All students have access to, and most students participate in, some form of career management learning at university. We assert that increased JSLGO may provide the motivation and focus needed to enhance the outcome of such learning opportunities (Barber et al., 1994; Noordzij et al., 2013). Importantly, research suggests that JSLGO is a characteristic that universities could enhance in their efforts to develop graduate employability (Dweck, 2006; Kozlowski et al., 2001).

Our theoretical contributions include firstly, an indirect explanation of how networking behaviour can be capitalized into employability by identifying access to resources as a central mechanism. Secondly, we advance social capital and networking literatures by identifying JSLGO as an individual intensifying characteristic. Thirdly, we add to the graduate employability literature by exploring these constructs in the university context, where such studies are scarce and empirical findings inconsistent.

Practically, identifying intervening mechanisms could help students and staff concerned with employability to capitalize on networking behaviour. This research is timely as expansion of 
the higher education sector has devalued the degree qualification as a differentiator (Tomlinson, 2008). Universities are thus under increasing pressure to enhance graduate employability at the same time as their resources are being squeezed (Avramenko, 2012; Finch et al., 2013; McMurray et al., 2016) and there are calls for more research into how this can be achieved (Bell, 2016; Finch et al., 2016). The focus on business students recognises that employability concerns might be higher for this group because expansion in graduate numbers is attributed mainly to vocationally oriented degrees such as those offered by business schools. Our chosen sample also accords with a renewed interest in the relevance of social capital to business (Simon, 2013). However, the findings may also be valuable to others with a concern for employability.

We start by reviewing the relevant literature, presenting our hypotheses and explaining our methodology. We then present results, conclusions, contributions to theory and practice and recommendations for further study to address our limitations.

\section{Theory and Hypothesis}

Networking behaviour, social capital and access to resources

Measures of networking typically assess the frequency of interrelated behaviours such as using contacts to get advice or discussing business matters outside of work (Wolff and Moser, 2009). Theory suggests these behaviours lead to informal, voluntary, and reciprocal relationships that in turn facilitate access to more resources, such as information and task related support (Podolny and Baron, 1997; Wolff, Moser and Grau, 2008). With the help of networking behaviour, individuals build relationships to form personal networks, these become embedded in bigger social networks such as classes and communities. These networks then provide access to various resources (Burt, 1997). 
The concept, potential benefits and risks of social capital continue to be debated, but there is recognition that is has two important characteristics, the structure and content of relationships (Adler and Kwon, 2002). The structural dimension or pattern of connections includes the size and spread of the network, whereas the content or relational dimension incorporates the nature or strength of connections (Nahapiet and Ghoshal, 1998). Networking is an individual behaviour that contributes to both characteristics and thus helps shape social capital (Wolff and Moser, 2009). Networking reaches out to new contacts and enhances the size of a personal network and so builds the structural dimension of social capital. Bigger and wider networks tend to increase the number of what are termed weak ties (Granovetter, 1973; Hansen, 1999), which are particularly important in materialising access to information as a benefit of social capital (Adler and Kwon, 2002). Networking can also affect the relational dimension of social capital. Increased frequency of interactions makes people more comfortable with each other and enhances cooperation (Levin et al., 2015). If relationships are nurtured it boosts trust and identity formation, with people more likely to share resources and help others in need (Pillai et al., 2016). This focus on quality of networking may create what are termed strong ties (Granovetter, 1973; Hansen, 1999) which can lead to social capital benefits of increased influence and solidarity (Adler and Kwon, 2002). In this study we explore the potential social capital benefit of enhanced employability for students, an outcome that is very relevant for university graduates (Flap and Boxman, 2001). In doing so we concentrate on networking in the university context leading to benefits through the mediating mechanism of access to resources (Adler and Kwon, 2002; Burt, 1992) and we offer three explanations for our choice.

Networking behaviour promotes a system of 'interconnected and cooperating individuals (Luthans, Hodgetts and Rosenkrantz, 1998, p. 120) with a key benefit of access to information (Adler and Kwon, 2002). The wider the social network the higher the potential value, as distant 
contacts, accessed less frequently, are more likely to have exclusive information (Brown and Konrad, 2001; Van Hoye et al., 2009). Access to potentially exclusive career related information, enables targeted applications, reduced competition and enhanced chances of success (Brown and Konrad, 2001; Zottoli and Wanous, 2000). Wider network relationships, or weak ties, may also have higher employability benefits as job seekers are more comfortable seeking employment information and support from more distant and less personal contacts (Granovetter, 1973). In the context of our study this may mean networking with a wide range of staff beyond the faculty such as central careers advisers or students from other courses.

Secondly, social relationships can influence third parties involved in recruitment through "putting in a good word", which can be decisive in selection situations (Stiff and Vugt, 2008). Similarly, strong social networks can elevate a job seekers credentials by suggesting they bring resources beyond their own set of skills, abilities and knowledge (Lin, 2001). Importantly, some social contacts exercise greater influencing power than others (Van Hoye et al., 2009). Thus instrumental and targeted networking could be productive in enhancing employability through the use of 'Calculative ties` (Huggins, Johnston and Thompson,(2012, p. 204).

Lastly, being a member of a network reinforces self-identity, status and provides emotional and social support, resulting in more robust mental health (Lin, 1999). For these reasons, we expect networking behaviour to be linked to access to resources.

Hypothesis 1: Networking behaviour is positively related to access to resources.

\section{Perceived employability and access to resources}

The literature indicates that perceived employability has both internal and external components (Rothwell, Herbert and Rothwell, 2008; van der Heijden, 2002). Internal relates to perceptions of abilities, ambition, career attributes and skills, whereas the external component includes 
items considered as outside the control of individuals such as labour market factors and demographics. The two dimensions are however intrinsically linked, in that internal dimensions impact how the external environment is viewed and vice versa (Fugate et al., 2004). We predict that access to resources derived from networking will be related to both components of perceived employability based on the underlying mechanisms of uncertainty management and affective adaptation.

Kramer (2004) suggests that individuals seek information to enhance a sense of control that reduces uncertainty to comfortable levels, and employment related activities are fraught with such daunting feelings. Information can make the future seem more predictable whilst the action of seeking it provides a sense of control (Seibert, Kraimer and Crant, 2001). Insecurity and uncertainty in the labour market affects all employees regardless of level or skill (Direnzo and Greenhaus, 2011), however it is more acute for the young (CIPD, 2015). In particular students may be concerned about their future employability as many have invested time and money in their studies in order to advance their careers (Perrone and Vickers, 2003; Tomlinson, 2008).

Affective adaptation is the willingness and ability to change in response to the environment (Fugate et al., 2004; McArdle et al., 2007). Ashford and Taylor (1990) identified affective adaptation requires flexibility to make changes and willingness to persevere with new behaviours. However, in order to identify the need for change, information and feedback are required accompanied by attributes to process this, such as optimism (Ashford and Taylor, 1990). For graduates, concerned with their employability, constant access to career related resources may enable them to identify changing employer needs, recognise how they might match these, and package and promote their strengths in response (Finch et al., 2016). 
Taken together, these arguments suggest that access to resources should increase both dimensions of perceived employability. Furthermore, we propose that access to resources mediates the relationship between networking and both dimensions of perceived employability.

Hypothesis 2: Access to resources is positively related to internal perceived employability.

Hypothesis 3: Networking behaviour is positively and indirectly related to internal perceived employability through access to resources in individuals' social networks.

Hypothesis 4: Access to resources is positively related to external perceived employability.

Hypothesis 5: Networking behaviour is positively and indirectly related to external perceived employability through access to resources in individuals' social networks.

The moderating role of job-search learning goal orientation (JSLGO).

Finally, because our study is situated within the university context, with its focus on learning, we also consider the possible moderating role of JSLGO. Our decision is based on the network capital literature. We argue that networking behaviour is a more general behaviour, which may have serendipitous employability outcomes. However, network capital theory posits that some individuals might be more calculating in their nature and thus behave more strategically when networking, actively working to create social ties and exploiting relationships for greater benefit (Bensaou, Galunic and Jonczyk-Sédès, 2014; Huggins et al., 2012). We suggest that in the university context students can learn the skills of such purposeful networking with staff and peers. Further, we posit that JSLGO might drive this narrower and more exploitative behaviour aimed at the specific goal of gaining employability related resources (Noordzij et al., 2013). 
Defined as a dynamic, self-regulatory and goal-orientated process, JSLGO occurs as a response to a discrepancy between an individual's employment goal and their current situation (Kanfer et al., 2001). JSLGO emphasizes developing competences, learning new things and tackling challenges in order to master job search, and can reduce preoccupation with failures and rejections (Barber et al., 1994; Noordzij et al., 2013). Thus, JSLGO provides focus and rationale for learning about career management strategies and techniques, which could include networking behaviours. Learning goal orientation is especially effective in complex tasks and where perseverance is an asset (Seijts et al., 2004) which aptly describes graduate job search and career management. Importantly in our context recent research suggests that situational goal orientations such as JSLGO can be developed (Dweck, 2006; Kozlowski et al., 2001).

Research shows that people may network strategically (Bensaou et al., 2014; Villar and Albertín, 2010), based on the notion that they want to exploit their social capital and in effect create network capital (Huggins et al., 2012). Therefore, it may be the case that increased JSLGO leads to more overt and strategic networking behaviour. Accordingly, those higher in JSLGO may use social contacts instrumentally, to receive relevant resources, rather than just network to socialize and build relationships per se. In which case individuals with high JSLGO are likely to have more access to career related resources. Therefore, we posit that JSLGO may intensify the relationship between networking behaviours and perceived employability that are mediated by access to resources.

Hypothesis 6: Job-search learning goal orientation moderates the relationship between networking behaviour and access to resources, with a stronger relationship for higher levels of JSLGO.

\section{Method}

Sample and Procedure 
Employability is highly relevant in the university context and, due to the vocational orientation of most business school degrees, is a high priority for these students. We therefore tested our hypotheses, by recruiting 376 full-time undergraduate students (10\% of the sample population) from a UK university business school. To minimise self-selection bias, participants were approached in taught sessions to complete a questionnaire (typically 15-20 min). Core units were used so that students from a range of degree courses were included.

Previous research shows variation in employability perception by academic level (Qenani, MacDougall and Sexton, 2014), therefore participants came from different undergraduate years: $36.7 \%$ first year students; $47.6 \%$ second year; and $15.7 \%$ third year. Our focus on first and second year students accords with McMuarray et al. (2016) who urge universities to promote employability throughout the degree programme, rather than just in the final year, as the skills and attributes required take time to develop and hone. Formal career management teaching for this sample begins part way through their second year, therefore it is only the final year students who will have benefitted from this input. The average age was 20.5 years, with an average 20.8 months of work experience and $57 \%$ were female. The university does not run any formal networking training although it is possible that some students may have participated in extra-curricular activities to develop networking behaviour.

\section{Measures}

All measures used a five-point scale: $1=$ Strongly disagree and $5=$ Strongly agree .

Perceived employability. Consistent with the concept having both external and internal factors we used the Rothwell et al (2008) questionnaire which has shown good reliability as well as construct and criterion validity in undergraduate contexts. Perceived external employability has eight items, e.g., "Employers are eager to employ graduates from my university". Perceived 
internal employability comprises five items, e.g., "I feel I could get any job so long as my skills and experience are reasonably relevant".

In response to the two theorized dimensions, we performed a confirmatory factor analysis (CFA) to verify the nature of the construct. We used the comparative fit index (CFI), TuckerLewis index (TLI), root-mean-square error of approximation (RMSEA), and standardized root mean square residual (SRMR) to assess fit (cf. Hu and Bentler, 1999). We first examined a model in which all 13 items were loaded onto one latent construct. Results showed a satisfactory fit $\left(\chi^{2}(56)=127.88, \mathrm{p}<.01, \mathrm{CFI}=.93, \mathrm{TLI}=.90, \mathrm{RMSEA}=.06, \mathrm{SRMR}=.05\right)$. We then examined a two-factor model in which the five and eight items loaded into separate latent constructs $\left(\chi^{2}{ }_{(55)}=121.12, \mathrm{p}<.01, \mathrm{CFI}=.94, \mathrm{TLI}=.91, \mathrm{RMSEA}=.06, \mathrm{SRMR}=.05\right)$. The two-factor model showed a better data fit $\left(\Delta \chi^{2}(1)=6.19, \mathrm{p}<.05\right)$, and was thus retained. The Cronbach's alphas were .75 (external) and .68 (internal).

Networking behaviour was measured using a six item scale from Ferris et al. (2005) adapted for the university context. An example item is: "I spend a lot of time at university developing connections with others", the Cronbach's alpha was .87 .

Job-searching learning goal orientation. A Cronbach's alpha of .90 was obtained using the four item scale of Noordzij et al. (2013). An indicative item is "I want to try to understand all procedures and activities in searching and applying for jobs”.

Access to Resources was measured using a scale adapted from Spreitzer (1996). Three items for access to information (e.g., "I have access to the information and support I need to make myself more employable") and three items for access to resources (e.g., "I understand the employability activities the university provides"). The two-factor latent structure provided a better fit with the data $\left(\chi^{2}{ }_{(6)}=10.05, \mathrm{p}<.01, \mathrm{CFI}=.99, \mathrm{TLI}=.99, \mathrm{RMSEA}=.04, \mathrm{SRMR}=\right.$ $.01)$, compared to the one factor solution $\left(\Delta \chi^{2}(1)=9.83, \mathrm{p}<.001\right)$. However, as the correlation 
between the two latent variables was high $(\mathrm{r}=.89)$ a one factor structure was retained $\left(\chi^{2}(7)=\right.$ $19.88, \mathrm{p}<.01, \mathrm{CFI}=.99, \mathrm{TLI}=.97, \mathrm{RMSEA}=.07, \mathrm{SRMR}=.02)$. The Cronbach's alpha was 87 .

Control variables were gender, previous work experience and year of study.

Analytical Strategy

We employed structural equation modelling (SEM) to test the theoretical model using MPLUS 7.2 (Muthén and Muthén, 1998-2012). SEM allows simultaneous estimation of multiple associations and yields an overall fit index of the hypothesized model (James, Mulaik and Brett, 2006). We adopted the two-step SEM strategy outlined by Anderson and Gerbing (1988). First, we used a measurement model fit to the observed data, then we compared nested structural models to find one that best accounts for covariances among the exogenous and endogenous constructs in the analysis. After this, we assessed the significance of the path estimates to test the hypotheses.

We used a bootstrapping approach suggested by Preacher and Hayes (2008) to examine the significance of indirect effects when testing the mediation hypotheses, namely the indirect effect of JSLGO on outcome variables via access to resources. Bootstrapping is considered a better approach for testing indirect effects than the traditional Sobel test because it imposes no assumptions about the distribution of indirect effects (Cheung and Lau, 2008; MacKinnon et al., 2002). In our analysis we followed the statistical routines developed by Preacher, Rucker, and Hayes (2007), estimating the indirect effects, and their confidence intervals, of JSLGO on outcome variables at different values of access to resources.

\section{Results}


Table 1 presents descriptive statistics and correlations for the measured variables, these are further explained and expanded in the following sections.

Insert Table 1 about here

\section{Measurement model}

The measurement model comprises the six latent constructs: networking behaviour, JSLGO, access to information, access to resources, perceived external employability and perceived internal employability. The CFA (Chin, 1998) produced index values indicating a good overall fit $\left(\chi^{2}{ }_{(354)}=622.46, \mathrm{p}<.05, \mathrm{CFI}=.94, \mathrm{TLI}=.93, \mathrm{RMSEA}=.04, \mathrm{SRMR}=.05\right)(\mathrm{Hu}$ and Bentler, 1999). All indicators loaded on their respective constructs significantly at the .05 level and all standardized paths were above .30. Thus, further examination of our hypothesized model was warranted.

\section{Structural model analysis}

We started by assessing our hypothesized model and found it achieved a satisfactory fit $\left(\chi^{2}(463)\right.$ $=811.47, \mathrm{p}<.01, \mathrm{CFI}=.92, \mathrm{TLI}=.91, \mathrm{RMSEA}=.04, \mathrm{SRMR}=.07)$, before comparing it with an alternative. Social capital theory suggests the importance of using the information and resources received from one's network (Adler and Kwon, 2002; Anderson, 2008). Therefore, we explored the possibility of a double moderation model. Thus, JSLGO moderates the relationship between network behaviour and access to resources and then later both dimensions of perceived employability. Thus, access to resources is more exploited by individuals with higher JSLGO increasing their perception of employability. This alternative model achieved an acceptable fit $\left(\chi^{2}{ }_{(490)}=885.96, \mathrm{p}<.01, \mathrm{CFI}=.91, \mathrm{TLI}=.90, \mathrm{RMSEA}=.05, \mathrm{SRMR}=.07\right)$. However we retained the first hypothesised model as the fit with the data was significantly 
better $\left(\Delta \chi^{2}(27)=74.49, \mathrm{p}<.01\right)$. For reasons of clarity the graphs generated by MPLUS software have been combined to create a simple representation of the hypothesized model (Figure 1) which shows the standardized path estimates. To maintain focus on the hypotheses, control variables are excluded from this figure, as only one appears to be significant, and this is discussed at the end of this section. Standardized coefficients are reported to enable assessment of relationship importance.

Hypothesis 1 , that networking is positively related to access to resources is supported $(\beta=.24$, $\mathrm{p}<.01)$. Hypothesis 2 and 4 are also supported with access to resources positively related to external perceived employability $(\beta=.39, \mathrm{p}<.01)$ and internal perceived employability $(\beta=$ $.36, \mathrm{p}<.01)$

Hypotheses 3 and 5: that access to resources mediates the relationship between networking behaviour and employability, were also supported. Using bootstrapping we resampled 1000 times and showed a significant positive indirect effect of networking behaviour on both internal perceived employability mediated by access to resources $(b=.06, \mathrm{CI}=.01, .11 \alpha=.05)$ and external perceived employability $(b=.06, \mathrm{CI}=.01, .12, \alpha=.05)$.

Insert Figure 1 about here

Hypothesis 6 predicts that JSLGO moderates the relationship between networking behaviour and access to resources. The interaction of JSLGO and networking behaviour is significant ( $\beta$ $=.33, \mathrm{p}<.01)$. Following Aiken and West (1991), we plotted the relationship between JSLGO and networking behaviours at $1 \mathrm{SD}$ above (high networking behaviour) and 1 SD below (low networking behaviour) the mean graphically (Figure 2). This shows networking behaviour provides less access to resources for individuals with lower JSLGO. However, the simple slope 
test confirms our findings that networking behaviour is still positively and significantly related to access to resources for both low $(\beta=0.27, \mathrm{p}<.01)$ and high JSLGO $(\beta=0.10, \mathrm{p}<.05)$. We further checked for slope differences between high and low JSLGO (Cohen et al., 2003) as our interactions seem to be ordinal rather than disordinal. The test suggested that the two slopes were significantly different $(\mathrm{t}=17.66, \mathrm{p}<.01)$, showing a variation between high and low JSLGO individuals.

The only proposed control variable (not shown in the Figure 1 for parsimonious reasons) with a significant relationship on the two dimensions of employability is the year of study. This showed a negative relationship between students' year of study and external perceived employability $(\beta=-.13, p<.05)$. This supports literature suggesting that heightened awareness of the labour market caused by temporal proximity for final year students increases concerns about their employability (Tomlinson, 2008; Tymon, 2013).

Insert Figure 2 about here

\section{Discussion}

Drawing on social capital theory, this study examines access to resources through networking and the individual outcome of perceived employability, alongside the intensifying role of JSLGO. In line with our hypotheses we found both networking and access to resources can directly increase internal and external perceptions of employability. Moreover, our results also show an indirect effect with access to resources being a mediator between networking behaviour and both dimensions of perceived employability. Furthermore, we found that JSLGO plays an important role in these complex processes by intervening in one particular 
mechanism. Both low and high JSLGO is related to networking behaviour and linked to greater access to resources. However, individuals with high JSLGO gain greater access to resources.

\section{Theoretical implications}

First, this study enriches our understanding of the complex process of networking by going beyond direct models. Based on social capital theory (Lin, 1999), we offer an indirect-based model in which access to resources serves as a mediating mechanism linking networking and perceptions of employability. We argue and find empirical support that, networking provides individuals with opportunities to use their social contacts to access information and resources that are relevant to their outcomes. This adds to the literature on networking within the university context (Hwang, Kessler and Francesco, 2004) and demonstrates that both characteristics of social capital, structure and content (Adler and Kwon, 2002; Nahapiet and Ghoshal, 1998) are important for graduate employability. This finding complements previous work in this domain, reinforcing the notion, that structural views provide just one side of the story. We show that behaviour individuals use in social networks is equally important (Kilduff and Brass, 2010) to both build relationship and access resources. and furthers the argument in general that social capital needs to be utilized and capitalized upon in order to be beneficial (Anderson, 2008).

Secondly, we expand the social network literature (Kalish and Robins, 2006), by identifying that one intensifying individual-level attribute, namely JSLGO, enhances access to resources acquired via networking and thus perceived employability. This builds upon network capital theory (Huggins, 2010). Our results suggest that networking behaviour can be a general antecedent of access to resources, but this relationship is strengthened by more focused behaviours such our proposed JSLGO. So, individuals that are more focused on job-search related issues will get more relevant resources out of their networks. Thus, we propose that 
JSLGO can and does drive more focused goal directed behaviour that enhances network capital to provide individuals with career supporting resources. This suggests that students like other individuals may develop relationships strategically as a means to an end (Bensaou et al., 2014; Huggins et al., 2012). Overall, we show that individuals tend to get the best results when there is a combination of both strategic exploitative and general networking behaviour.

Thirdly, this study broadens understanding of networking in the higher education environment answering calls for more research into how graduate employability can be enhanced (Bell, 2016; Finch et al., 2016). Networking is known to be valuable for career management in general (Seibert, Kraimer and Liden, 2001; Wolff and Moser, 2009) and securing employment in particular (Burt, 1997; Granovetter, 1973; Wanberg et al., 2000). However, in the university context much less is known. Our results not only show that networking, access to resources and JSLGO are all valuable in enhancing graduate employability, but how they interact and can therefore complement each other.

\section{Practical implications}

These results have implications for both individuals interested in career planning and those who support them. First, individuals have much to gain by developing networking behaviours as this facilitates access to resources related to employability. Importantly, networking behaviours can be developed (de Janasz and Forret, 2008) and therefore we suggest providers of career guidance should offer training and individuals should seek this out.

Obvious beneficiaries are students, many of whom have invested in higher education in order to enhance their careers, and universities who face increasing pressure to enhance graduate employability, with diminishing resources (Bridgstock, 2009; Qenani et al., 2014). There is evidence that networking is developed through work-based learning and placements, thus encouragement of these is recommended (Cranmer, 2006). Additionally, networking 
behaviours can be overtly taught via stand-alone, extra-curricular activities, such as professional skills workshops, or be more subtly nurtured through activities embedded in the curriculum, by for example collaborative assignments. Both can and should be considered.

Our second practical implication concerns the value of JSLGO. Higher levels are associated with greater access to relevant resources, leading to enhanced employability, and indicating a more strategic approach (Bensaou et al., 2014; Villar and Albertín, 2010). Some assert that JSLGO can be developed (DeShon and Gillespie, 2005; Dweck, 2006). Example methods include: demonstrating the relevance of employability, developing strategic networking skills, and teaching the importance of both accessing and utilizing resources embedded in networks. In the university context, this can again be done via both stand-alone events or embedded activities. Using both methods would appeal to students both low and high on JSLGO. Those high on JSLGO are more likely to have the motivation to embrace extra-curricular activities, whereas those with lower levels may be less likely to do so but would benefit from embedded learning.

\section{Limitations and future research directions}

Like most, this study has limitations such as the cross-sectional design precluding verification of a causal relationship. For example, it may be that low perceived employability will motivate individuals to network more, resulting in greater access to resources. Longitudinal studies examining sequences in the relationships among networking behaviour, access to resources and employability are therefore suggested. These could also potentially explore the relationship between employability and career paths (Direnzo, Greenhaus and Weer, 2015) and provide interesting insights into individual decisions on how social networks are used. A further limitation that could be addressed in future studies is to collect data on exposure to additional 
formal or informal career management and networking initiatives which could potentially influence outcomes.

We also suggest future research could take a more nuanced approach to explore the quality of networking or strategies individuals use and the social costs of such behaviour (Bensaou et al., 2014; Villar and Albertín, 2010). Another potential enhancement would be to build upon the direct and indirect relationships that are tested in our model. For example, further exploring other relationships, using more complex approaches and alternative theoretical underpinning. One such possibility is to test a moderated mediation model with a PROCESS (Hayes, 2013) or use the Preacher et al. (2007) MPLUS code.

Finally, moderators other than JSLGO should be considered. For example proactivity, because individuals with high levels tend to challenge the status quo in looking for change (Crant, 2000).

\section{Conclusion}

Using the over-arching framework of social capital theory this study contributes to the literature by suggesting that access to resources is a mediating mechanism between networking and employability perceptions. We also found that job-search learning goal orientation (JSLGO) strengthens networking behaviours and provides individuals with more resources. This enriched perspective highlights potential benefits of developing networking ability and JSLGO for individuals concerned about their careers and those charged with supporting them. Practically we suggest methods for developing networking behaviours and enhancing JSLGO particularly in the higher education context, where employability is becoming increasingly important to students and universities. 


\section{References}

Adler, P.S. \& Kwon, S.W. (2002), 'Social capital: prospects for a new concept', Academy of Management Review, Vol. 27, No. 1, pp. 17-40.

Aiken, L.S., West, S.G. \& Reno, R.R. (1991), Multiple regression : testing and interpreting interactions, SAGE, Thousand Oaks ; London.

Anderson, J.C. \& Gerbing, D.W. (1988), 'Structural equation modeling in practice: A review and recommended two-step approach', Psychological Bulletin, Vol. 103, No. 3, pp. 411-23.

Anderson, M.H. (2008), 'Social networks and the cognitive motivation to realize network opportunities: a study of managers' information gathering behaviors', Journal of Organizational Behavior, Vol. 29, No. 1, pp. 51-78.

Ashford, S.J. \& Taylor, M.S. (1990), 'Adaptation to work transitions: An integrative approach', in G.R. Ferris \& K.M. Rowland (eds), Research in personnel and human resources management, vol. 8, JAI Press, Greenwich, CT, pp. 1-39.

Avramenko, A. (2012), 'Enhancing students' employability through business simulation', Education + Training, Vol. 54, No. 5, pp. 355-67.

Barber, A.E., Daly, C.L., Giannantonio, C.M. \& Phillips, J.M. (1994), 'Job search activities: An examination of changes over time.', Personnel Psychology, Vol. 47, No. 4, pp. 739-66.

Bell, R. (2016), 'Unpacking the link between entrepreneurialism and employability: An assessment of the relationship between entrepreneurial attitudes and likelihood of graduate employment in a professional field', Education + Training, Vol. 58, No. 1, pp. 2-17.

Bensaou, B.M., Galunic, C. \& Jonczyk-Sédès, C. (2014), 'Players and Purists: Networking Strategies and Agency of Service Professionals', Organization Science, Vol. 25, No. 1, pp. 29-56.

Bridgstock, R. (2009), 'The graduate attributes we've overlooked: enhancing graduate employability through career management skills', Higher Education Research \& Development, Vol. 28, No. 1, pp. 31-44.

Brown, D.W. \& Konrad, A.M. (2001), 'Granovetter Was Right: The Importance of Weak Ties to a Contemporary Job Search', Group \& Organization Management, Vol. 26, No. 4, pp. 434-62.

Burt, R.S. (1992), Structural Holes: The Social Structure of Competition, Harvard University Press, Harvard.

Burt, R.S. (1997), 'The contingent value of social capital', Administrative Science Quarterly, Vol. 42, No. 2, pp. 339-65. 
Cheung, G.W. \& Lau, R.S. (2008), 'Testing Mediation and Suppression Effects of Latent Variables: Bootstrapping With Structural Equation Models', Organizational Research Methods, Vol. 11, No. 2, pp. 296-325.

Chin, W.W. (1998), 'Commentary: Issues and Opinion on Structural Equation Modeling', MIS Quarterly, Vol. 22, No. 1, pp. vii-xvi.

CIPD (2015), 'How much trouble is Europe really in?', Work. Because business is about people., CIPD, London, pp. 50-7.

Cohen, J., Cohen, P., West, S.G. \& Aiken, L.S. (2003), Applied multiple regression/correlation analysis for the behavioral sciences, Lawrence Erlbaum Associates, London.

Cranmer, S. (2006), 'Enhancing graduate employability: best intentions and mixed outcomes', Studies in Higher Education, Vol. 31, No. 2, pp. 169-84.

Crant, J.M. (2000), 'Proactive Behavior in Organizations', Journal of Management, Vol. 26, No. 3, pp. 435-62.

de Janasz, S.C. \& Forret, M.L. (2008), 'Learning The Art of Networking: A Critical Skill for Enhancing Social Capital and Career Success', Journal of Management Education, Vol. 32, No. 5, pp. 629-50.

DeShon, R.P. \& Gillespie, J.Z. (2005), 'A Motivated Action Theory Account of Goal Orientation', Journal of Applied Psychology, Vol. 90, No. 6, pp. 1096-127.

Direnzo, M.S. \& Greenhaus, J.H. (2011), 'Job Search and Voluntary Turnover in a Boundaryless world: a Control Theory Perspective', Academy of Management Review, Vol. 36, No. 3, pp. 567-89.

Direnzo, M.S., Greenhaus, J.H. \& Weer, C.H. (2015), 'Relationship between protean career orientation and work-life balance: A resource perspective', Journal of Organizational Behavior, Vol. 36, No. 4, pp. 538-60.

Dweck, C.S. (2006), Mindset: The new psychology of success, Random House, New York.

Ferris, G.R., Treadway, D.C., Kolodinsky, R.W., Hochwarter, W.A., Kacmar, C.J., Douglas, C. \& Frink, D.D. (2005), 'Development and Validation of the Political Skill Inventory', Journal of Management, Vol. 31, No. 1, pp. 126-52.

Finch, D.J., Hamilton, L.K., Baldwin, R. \& Zehner, M. (2013), 'An exploratory study of factors affecting undergraduate employability', Education + Training, Vol. 55, No. 7, pp. 681-704.

Finch, D.J., Peacock, M., Levallet, N. \& Foster, W. (2016), 'A dynamic capabilities view of employability: Exploring the drivers of competitive advantage for university graduates', Education + Training, Vol. 58, No. 1, pp. 61-81.

Flap, H.D. \& Boxman, E. (2001), 'Getting Started: The Influence of Social Capital on the Start of the Occupational Career', in N. Lin, S.K. Cook \& R.S. Burt (eds), Social Capital: Theory and Research, Aldine de Gruyter, New York, pp. 159-84. 
Fugate, M., Kinicki, A.J. \& Ashforth, B.E. (2004), 'Employability: A psycho-social construct, its dimensions, and applications', Journal of Vocational Behavior, Vol. 65, No. 1, pp. 14-38.

Granovetter, M.S. (1973), 'The Strength of Weak Ties', American Journal of Sociology, Vol. 78, No. 6, pp. 1360-80.

Hansen, M.T. (1999), 'The Search-Transfer Problem: The Role of Weak Ties in Sharing Knowledge across Organization Subunits.', Administrative Science Quarterly, Vol. 44, No. 1, pp. 82-111.

Hayes, A.F. (2013), Introduction to mediation, moderation, and conditional process analysis: A regression-based approach, Guilford Press, New York.

Hu, L.t. \& Bentler, P.M. (1999), 'Cutoff criteria for fit indexes in covariance structure analysis: Conventional criteria versus new alternatives', Structural Equation Modeling: A Multidisciplinary Journal, Vol. 6, No. 1, pp. 1-55.

Huggins, R. (2010), 'Forms of Network Resource: Knowledge Access and the Role of InterFirm Networks', International Journal of Management Reviews, Vol. 12, No. 3, pp. 335-52.

Huggins, R., Johnston, A. \& Thompson, P. (2012), 'Network Capital, Social Capital and Knowledge Flow: How the Nature of Inter-organizational Networks Impacts on Innovation', Industry and Innovation, Vol. 19, No. 3, pp. 203-32.

Hwang, A., Kessler, E.H. \& Francesco, A.M. (2004), 'Student Networking Behavior, Culture, and Grade Performance: An Empirical Study and Pedagogical Recommendations', Academy of Management Learning \& Education, Vol. 3, No. 2, pp. 139-50.

James, L.R., Mulaik, S.A. \& Brett, J.M. (2006), 'A Tale of Two Methods', Organizational Research Methods, Vol. 9, No. 2, pp. 233-44.

Kalish, Y. \& Robins, G. (2006), 'Psychological predispositions and network structure: The relationship between individual predispositions, structural holes and network closure', Social Networks, Vol. 28, No. 1, pp. 56-84.

Kanfer, R., Wanberg, C.R. \& Kantrowitz, T.M. (2001), 'Job search and employment: A personality-motivational analysis and meta-analytic review', Journal of Applied Psychology, Vol. 86, No. 1, pp. 837-55.

Kilduff, M. \& Brass, D.J. (2010), 'Organizational Social Network Research: Core Ideas and Key Debates', The Academy of Management Annals, Vol. 4, pp. 317 - 57.

Kramer, M.W. (2004), Managing uncertainty in organizational communication, Lawrence Erlbaum, Mahwah.

Levin, D.Z., Walter, J., Appleyard, M.M. \& Cross, R. (2015), 'Relational Enhancement: How the Relational Dimension of Social Capital Unlocks the Value of Network-Bridging Ties', Group \& Organization Management. 
Lin, N. (1999), 'Building a network theory of social capital', Connections, Vol. 22, No. 1, pp. 28-51.

Lin, N. (2001), Social Capital: A Theory of Social Structure and Action., Cambridge University Press, Cambridge.

Luthans, F., Hodgetts, R.M. \& Rosenkrantz, S.A. (1998), Real managers, Ballinger, Cambridge, MA.

MacKinnon, D.P., Lockwood, C.M., Hoffman, J.M., West, S.G. \& Sheets, V. (2002), 'A comparison of methods to test mediation and other intervening variable effects', Psychological Methods, Vol. 7, No. 1, pp. 83-104.

McArdle, S., Waters, L., Briscoe, J.P. \& Hall, D.T. (2007), 'Employability during unemployment: Adaptability, career identity and human and social capital', Journal of Vocational Behavior, Vol. 71, No. 2, pp. 247-64.

McMurray, S., Dutton, M., McQuaid, R. \& Richard, A. (2016), 'Employer demands from business graduates', Education + Training, Vol. 58, No. 1, pp. 112-32.

Muthén, L.K. \& Muthén, B.O. (1998-2012), Mplus User's Guide, 7th edn, Muthén \& Muthén, Los Angeles, CA.

Nahapiet, J. \& Ghoshal, S. (1998), 'Social capital, intellectual capital, and the organizational advantage', Academy of Management Review, Vol. 23, No. 2, pp. 242-66.

Noordzij, G., van Hooft, E.A.J., van Mierlo, H., van Dam, A. \& Born, M.P. (2013), 'The Effects of a Learning-Goal Orientation Training on Self-Regulation: A Field Experiment Among Unemployed Job Seekers', Personnel Psychology, Vol. 66, No. 3, pp. 723-55.

Perrone, L. \& Vickers, M.H. (2003), 'Life after graduation as a "very uncomfortable world": an Australian case study', Education + Training, Vol. 45, No. 2, pp. 69-78.

Pillai, K.G., Hodgkinson, G.P., Kalyanaram, G. \& Nair, S.R. (2016), 'The Negative Effects of Social Capital in Organizations: A Review and Extension', International Journal of Management Reviews, pp. n/a-n/a.

Podolny, J.M. \& Baron, J.N. (1997), 'Resources and Relationships: Social Networks and Mobility in the Workplace', American Sociological Review, Vol. 62, No. 5, pp. 67393.

Preacher, K.J. \& Hayes, A.F. (2008), 'Asymptotic and resampling strategies for assessing and comparing indirect effects in multiple mediator models', Behavior Research Methods, Vol. 40, No. 3, pp. 879-91.

Preacher, K.J., Rucker, D.D. \& Hayes, A.F. (2007), 'Addressing Moderated Mediation Hypotheses: Theory, Methods, and Prescriptions', Multivariate Behavioral Research, Vol. 42, No. 1, pp. 185-227.

Qenani, E., MacDougall, N. \& Sexton, C. (2014), 'An empirical study of self-perceived employability: Improving the prospects for student employment success in an 
uncertain environment', Active Learning in Higher Education, Vol. 15, No. 3, pp. 199-213.

Rothwell, A., Herbert, I. \& Rothwell, F. (2008), 'Self-perceived employability: Construction and initial validation of a scale for university students', Journal of Vocational Behavior, Vol. 73, No. 1, pp. 1-12.

Seibert, S.E., Kraimer, M.L. \& Crant, J.M. (2001), 'What do proactive people do? A longitudinal model linking proactive personality and career success', Personnel Psychology, Vol. 54, No. 4, pp. 845-74.

Seibert, S.E., Kraimer, M.L. \& Liden, R.C. (2001), 'A Social Capital Theory of Career Success', The Academy of Management Journal, Vol. 44, No. 2, pp. 219-37.

Seijts, G.H., Latham, G.P., Tasa, K. \& Latham, B.W. (2004), 'Goal Setting and Goal Orientation: An Integration of Two Different Yet Related Literatures', Academy of Management Journal, Vol. 47, No. 2, pp. 227-39.

Simon, B. (2013), 'Reflections on the omission of social capital from enterprise education and business start training', Education + Training, Vol. 55, No. 8/9, pp. 899-910.

Spreitzer, G.M. (1996), 'Social Structural Characteristics of Psychological Empowerment', The Academy of Management Journal, Vol. 39, No. 2, pp. 483-504.

Stiff, C. \& Vugt, M.V. (2008), 'The Power of Reputations: The Role of Third Party Information in the Admission of New Group Members', Group Dynamics: Theory, Research, \& Practice, Vol. 12, No. 2, pp. 155-66.

Tomlinson, M. (2008), 'The degree is not enough': students' perceptions of the role of higher education credentials for graduate work and employability', British Journal of Sociology of Education, Vol. 29, No. 1, pp. 49-61.

Tymon, A. \& Batistic, S. (2016), 'Improved academic performance and enhanced employability? The potential double benefit of proactivity for business graduates', Teaching in Higher Education, Vol. 21, No. 8, pp. 915-32.

van der Heijden, B. (2002), 'Prerequisites to guarantee life- long employability', Personnel Review, Vol. 31, No. 1, pp. 44-61.

Van Hoye, G., van Hooft, E.A.J. \& Lievens, F. (2009), 'Networking as a job search behaviour: A social network perspective', Journal of Occupational and Organizational Psychology, Vol. 82, No. 3, pp. 661-82.

Villar, E. \& Albertín, P. (2010), 'It is who knows you'. The positions of university students regarding intentional investment in social capital', Studies in Higher Education, Vol. 35, No. 2, pp. 137-54.

Wanberg, C.R., Kanfer, R. \& Banas, J.T. (2000), 'Predictors and Outcomes of Networking Intensity Among Unemployed Job Seekers', Journal of Applied Psychology, Vol. 85, No. 4, pp. 491-503. 
Wolff, H.-G. \& Moser, K. (2009), 'Effects of Networking on Career Success: A Longitudinal Study', Journal of Applied Psychology, Vol. 94, No. 1, pp. 196-206.

Wolff, H.-G., Moser, K. \& Grau, A. (2008), 'Networking: Theoretical foundations and construct validity', in J. Deller (ed.), Readings in applied organizational behavior from the Lüneburg symposium - Personality at work Rainer Hampp, Mering, Germany, pp. 101-18.

Zottoli, M.A. \& Wanous, J.P. (2000), 'Recruitment Source Research: Current Status and Future Directions', Human Resource Management Review, Vol. 10, No. 4, pp. 353-82. 


\section{FIGURE 1}

Standardized Path Estimates of the Hypothesized Model

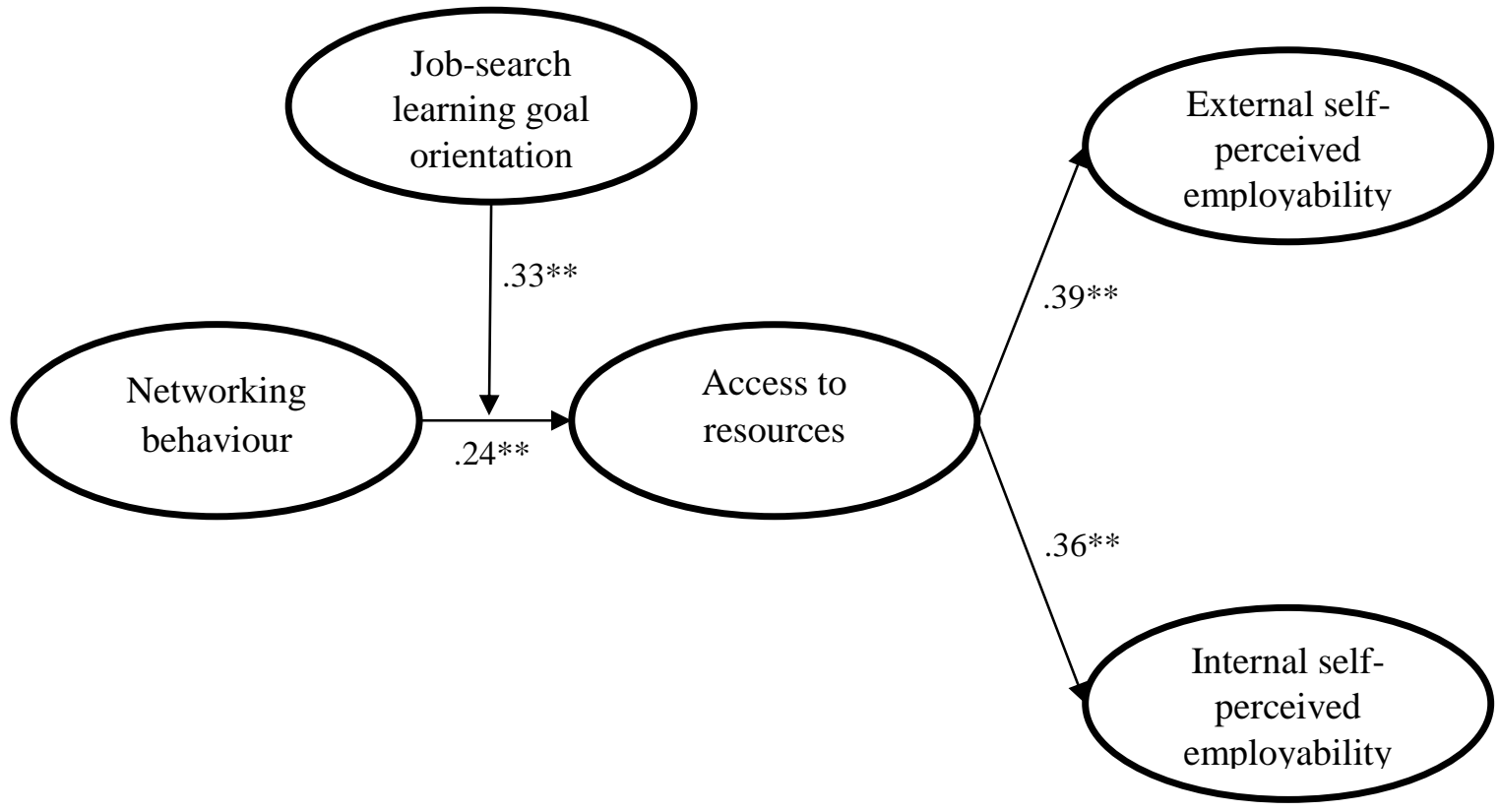

$* \mathrm{p}<.05 ; * * \mathrm{p}<.01$ 


\section{FIGURE 2}

Interaction of networking behaviour and job-search learning goal orientation on access to resources
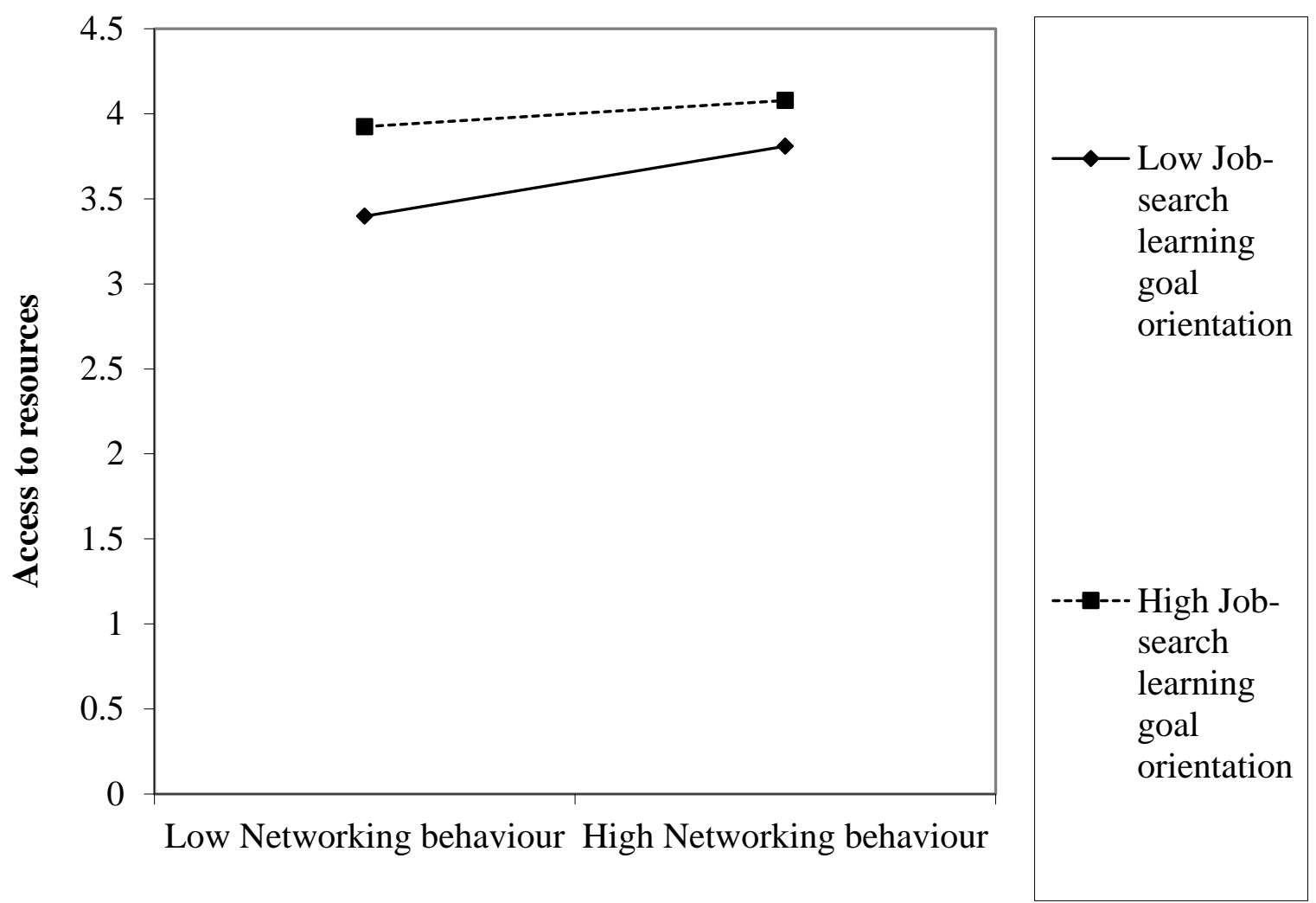


\section{TABLE 1}

Means, standard deviations, and correlations among the variables

\begin{tabular}{|c|c|c|c|c|c|c|c|c|c|c|c|}
\hline & Variable & Mean & SD & 1 & 2 & 3 & 4 & 5 & 6 & 7 & 8 \\
\hline 1 & $\begin{array}{l}\text { Gender }(0= \\
\text { Male, } 1= \\
\text { Female })\end{array}$ & .43 & .50 & - & & & & & & & \\
\hline 2 & Year of Study & 1.79 & .69 & -.04 & - & & & & & & \\
\hline 3 & $\begin{array}{l}\text { Previous work } \\
\text { experience }\end{array}$ & 21.80 & 35.08 & -.07 & .09 & - & & & & & \\
\hline 4 & $\begin{array}{l}\text { External self- } \\
\text { perceived } \\
\text { employability }\end{array}$ & 3.38 & .51 & .00 & $-.13^{*}$ & .03 & $(.75)$ & & & & \\
\hline 5 & $\begin{array}{l}\text { Internal self- } \\
\text { perceived } \\
\text { employability }\end{array}$ & 3.53 & .59 & -.03 & .05 & $.13^{*}$ & $.46^{* *}$ & $(.68)$ & & & \\
\hline 6 & $\begin{array}{l}\text { Networking } \\
\text { behaviour }\end{array}$ & 3.19 & .74 & $-.12 *$ & -.05 & .06 & $.32 * *$ & $.32 * *$ & $(.87)$ & & \\
\hline 7 & $\begin{array}{l}\text { Job-search } \\
\text { learning goal } \\
\text { orientation }\end{array}$ & 4.17 & .79 & $.13 *$ & .08 & -.01 & $.27 * *$ & $.26^{* *}$ & .09 & $(.90)$ & \\
\hline 8 & $\begin{array}{l}\text { Access to } \\
\text { resources }\end{array}$ & 3.80 & .65 & $.16^{* *}$ & -.01 & .08 & $.38 * *$ & $.36 * *$ & $.26^{* *}$ & $.34 * *$ & $(.87)$ \\
\hline
\end{tabular}

Coefficient alphas are on the diagonal in parentheses. Previous work experience is in months.

$* \mathrm{p}<.05, * * \mathrm{p}<.01 . \mathrm{n}=376$ 